\title{
BRIAN BIX AND MEXICAN LEGAL PHILOSOPHY: A COMMENT FROM THE PERSPECTIVE OF THE SOCIOLOGY OF KNOWLEDGE*
}

\author{
Enrique CÁCERES NIETO
}

Resumen:

El objetivo de este comentario es proporcionar algunas razones a favor de la importancia de la publicación de la traducción al español del libro de Brian Bix "Jurisprudence, Theory and Context" para la actualización de la filosofía del derecho en México. Mi comentario es realizado desde la perspectiva de la sociología del conocimiento y tiene como punto de partida un estudio empírico sobre el estado del arte de la filosofía del derecho en las facultades de derecho del país. Mi conclusión es que el trabajo de Brian Bix responde la pregunta fundamental: ¿cómo incorporar a la filosofia del derecho mexicana al contexto global?, que estudiantes, profesores y jóvenes investigadores se plantean actualmente.

Palabras clave:

Filosofia jurídica, teoría del derecho, sociología del conocimiento, constructivismo jurídico, filosofia del derecho.

* This talk was given at the book presentation of Brian Bix's Jurisprudence: Theory and Context, held at the Legal Research Institute, UNAM September, 1st 2011. 


\title{
ENRIQUE CÁCERES NIETO
}

\begin{abstract}
:
My aim in this comment is to provide reasons that highlight the importance of the Spanish translation of Brian Bix's book: "Jurisprudence, Theory and Context". My comment stems from the sociology of knowledge and takes as a point of departure an empirical study about the state of the art of legal philosophy in Mexican Law Schools. My conclusion is that Brian Bix's work shows how Mexican legal philosophy might be incorporated into current jurisprudential debate.
\end{abstract}

\section{Keywords:}

Legal Philosophy, Jurisprudence, Sociology of Knowledge, Legal Constructivism, Philosophy of Law. 
Summary: I. Introduction. II. Focus of the Presentation. III. The Questions. IV. The Books that Are Used to Teach Legal Philosophy in Mexico: State of the Art. V. The Four Main Questions in Professor Bix's Work.

\section{INTRODUCTION}

First of all, I wish to say that it is an honor for me to introduce to the audience the Spanish version of Brian Bix's "Jurisprudence, Theory and Context" (or "Filosofia del Derecho: Ubicación de los problemas en su contexto", in Spanish). Second, I would also like to thank Juan Vega, coordinator -and participant - of the Spanish translation, Imer Flores and Rodrigo Ortiz that contributed greatly to the finished product.

\section{Focus of THE PRESENTATION}

In these kinds of events it is expected that people make a general description of the book in question, and that they elaborate on the positive and negative aspects of the work.

I will deviate from this line. I am sure that my colleagues in this panel will perform exceptionally well at it; particularly those who had to face the difficult task of reconstructing the author's thought in another language.

This time, my objective is to offer reasons in support of the following thesis:

That the appearance of the Spanish version of Professor Bix's book is likely to give rise to a "before-and-after" scenario, not only limited to the Mexican context but also in the whole region of Latin America, considering the state of things surrounding this discipline and the reach that our Institute's publications have throughout the region.

In order to support this thesis, my point of departure will be what I call a "weak version of the sociology of knowledge".

In addition, I wish to state that Professor Bix's thought has also influenced my own academic work, particularly two articles to which I will refer to during the presentation. 
The first article is called "Philosophy of Law in the Twenty First Century in Mexico: State of the art and perspectives"; 1 the second article is entitled "On the advantages of studying legalphilosophy (meta-theoretical remarks fron the Legal Constructivism)2", published by the legal journal "El Siete" ran by a mutual student, Luis Navarrete.

\section{The Questions}

Based on the results of my research reported in "Philosophy of Law in the Twenty First Century in Mexico: State of the art and perspectives", I hold that in this country there are four questions that remain unanswered in the books addressing the subject, which are:
A) Are there reasons to study "Philosophy of Law"?
B) How to study the subject?
C) What topics must be taught?
D) How to become a legal philosopher?
Let me justify the previous assertion:

\section{The Books that are Used to Teach Legal Philosophy In MeXico: State of THE ART}

\section{A) The Problem}

What is the state of the art in this subject?

This is a tricky question because it encapsulates more than one seemingly simple and direct question, all of which one has to address in order to provide a satisfactory answer.

These related or implied questions are, at least, the following: What may be a general characterization of the literature (books, papers, and so on) that address legal philoso-

1 Cáceres Nieto, Enrique, "La filosofia del derecho en México en el siglo XXI: situación y perspectivas", en García Ramírez, Sergio (coord.), El derecho en México: dos siglos (1810-2010), 2010, t. VIII, pp. 207-264.

2 Cáceres Nieto, Enrique, "Sobre la utilidad del estudio de la filosofia del derecho (apuntes meta-teóricos desde el constructivismo jurídico)", El Siete, Revista, México, núm. 13, 2009, pp. 5-20. 
phy? What are the pedagogical techniques used to teach it? What are the objectives, problems and content that are supposed to be addressed in class according to the general programs on the subject? What is the relationship between 'legal philosophy' and other subjects? What is the state of the art regarding ordinary and advanced research in legal philosophy?

The prior set of questions, is nonetheless still incomplete. A satisfactory account of legal philosophy requires an answer to a more foundational type of question: What does 'legal philosophy" mean? How does it differ from other philosophical endeavors addressing practical reasoning, such as political and moral philosophy? Are there genuine border lines? Are there legitimate overlaps?

B) The Importance of the Books that are Used to Teach Legal Philosophy: A Constructivist Approach

For quite some years now, I have focused my attention on developing a theoretical view of the law which I call "Legal Constructivism". My objective is to study how the law and its discourses have an incidence on the way social reality is progressively and constantly constructed. I engage in this kind of philosophical reflection using cognitive sciences' insights. In this sense I propose a kind of naturalized jurisprudence (following Leiter).

From this perspective, as in the case of science, I hold that the legal theories taught in texts trigger the creation of mental models which are structured belief-systems that determine how we perceive and comprehend certain aspects of the world.

I will recourse to the successive approximation method to provide a full account of the previous assertion:

\section{Initial Approximation: The True Magic in Harry Potter}

When we read a fiction novel, our mind transforms words into internal images that have the status of fiction (the 
propositional attitude normally attached to them is "I do not believe that X").

\section{Second Approximation: History Books}

It is common to say that history is written by winners. Despite of this, we may say that there is not much of a difference between history texts (that tell us the official version of some facts) and Harry Potter-like novels. They are both narratives that give rise to mental images within us. One of the differences is that in the case of history books, their narrative gives rise to mental models to which we normally attach epistemic value: "I believe it was the case that $\mathrm{X}$, and that X was indeed true".

It is important to mention that sharing mental models generated by history books amounts to sharing the same set of "social representations" that together form the social adhesive of national identity, the sense of continuity over time, and so on.

\section{Third Approximation: Science Texts}

\section{and Scientists' Formation}

Following Kuhn, we might state that new scientists' cognitive and heuristic structures are a product of a complex socialization process where new scientists are exposed to the current scientific paradigms through their contact with elementary science text books, and advanced research papers.

In Kuhn's own words, these texts serve the purpose of "defining legitimate problems and methods of a research field for the advantage of future generations". ${ }^{3}$

Regarding "paradigms", Kuhn claims that:

"The study of paradigms prepares the student to be a part of the scientific community within which she will work in the fu-

See Kuhn, Thomas, La estructura de las revoluciones científicas, México, Fondo de Cultura Económica, 2008, p. 33. 
ture. Shared-paradigm-based research provides a normative structure for those engaged in practicing science". 4

\section{Legal Philosophy Texts}

My research on Knowledge Elicitation, Knowledge Representation, Artificial Intelligence and Law, Applied Cognitive Psychology, and Cognitive Task Analysis reveals that legal theories (or theories of the law) may constitute an important part of the mental models that legal operators use to organize legally relevant information.

Subscribing to a particular theory of law means to attach the epistemic status of a true belief to most of the propositions that constitute the theory. If someone said that she subscribes to Hart's theory of law but that she thinks its propositions are mostly false, that would be as odd as asserting that "the cat is on the floor but I don't think so".

To sum up, if we link theories of law with decision theory as proposed by cognitive sciences, it becomes clear that these theories of law may play a very important practical role in decision-making processes.

In this line, the one who solves a legal contradiction between hierarchically different legal norms assumes that legal systems have a hierarchical structure. This is not an assumption required by "positive law" like a statute, but it is a theoretical postulate (Kelsen's theory comes to mind, and the like).

Sometimes, mental models that theories of law give rise to are not just complementary components of legislation but the sole and only basis for solving a legal dispute and making legal (practical) decisions. The cases of military officers in the Argentinean military regime claiming that they did what they did because they were following orders is a clear example of this phenomenon.

Legal mental models arising from theories of law also perform the role of making legal thought homogeneous across

\footnotetext{
4 Ibidem, p. 34.
} 
different jurisdictions (despite the particular differences in the content of positive laws), which is clear when someone enrolls in a Law Masters degree program in a different country. In these cases, the particular content of the laws of the host country are integrated into a structure-matching procedure that takes place within the mental most abstract (theoretical) models of the cognizing agent.

\section{Legal Philosophy Texts in Mexico}

With the purpose of analyzing the contribution that legal philosophy texts may be making to Mexican legal operators' mental models, I designed an exploratory empirical study in order to identify what were the main textbooks used by legal philosophy teachers, and to measure the convergence (or lack of it) of 111 different legal philosophy teaching plans.

One of the main insights of the study was a surprising lack of uniformity regarding the content that is supposedly taught across different but related philosophical subjects.

Two books have the most important influence across the nation. The rest of them contain a miscellaneous of various topics. Sometimes their authors do not have any formal education in philosophy, and in each and every case, there is an absence of the problems that characterize the contemporary and state of the art discussion on legal philosophy.

A more detailed analysis on the texts that are used is the following:

1) The bibliography on legal philosophy is obsolete.

2) The most influential books go back to the origins of Mexican legal philosophy.

3) The same book tends to be analyzed in different philosophical disciplines.

4) Contemporary books and the original works do not have a great influence.

5) Teachers prefer to use elementary or peripheral literature instead of motivating students to read the classics. In this line, students finish their legal studies knowing (or re- 
citing) a bunch of clichés or encapsulated formulas that distort the thought of the author.

6) Some of the suggested readings for legal philosophy courses include non-philosophical, nonetheless legal-technical textbooks, such as books having to do with the theory of the legal process, criminal law, and so on.

7) Contemporary authors are ignored.

8) The pedagogical technique widely spread is that of the lecture-format, where students are asked to memorize some concepts (at best).

9) With few exceptions (such as Carlos Nino's work "Introducción al análisis del derecho"5), the texts do not promote the emergence of procedural knowledge (or "how-to" knowledge). This is paradoxical in that legal philosophy courses are supposed to enhance the students' capacity to perform legal and argumentative analysis.

10) It is never the case that the teacher discusses legal philosophy papers in class, which on its turn means that students do not have the opportunity to get acquainted with international journals of the subject, and with the problems discussed by contemporary authors.

11) No book provides an answer to what we have considered here as the four main questions: Are there reasons to study "Philosophy of Law"? How to study the subject? What topics must be taught? How to become a legal philosopher?

\section{The Four Main Questions in Professor BiX’s Work}

\section{A) Are There Reasons to Study "Philosophy of Law"?}

Despite their surface similarities in syntax and pronunciation, the English word 'jurisprudence' and the Spanish word 'jurisprudencia' have different meanings.

'Jurisprudence' is a synonym of 'legal philosophy' or 'legal theory'. When translated to Spanish 'Jurisprudence' does

5 Nino, Carlos Santiago, Introducción al análisis del derecho, 8a. ed., Buenos Aires, Ariel, 1977. 
not only mean 'filosofia del derecho', or 'teoría general del derecho'. For example, Kelsen's "Pure Theory of Law", and Hart's "The Concept of Law" are typical instances of the kind of theoretical work denoted by this sense of the expression. I will refer to this sense as 'Jurisprudence 1'.

By contrast, the Spanish term 'jurisprudencia' is ambiguous and has at least two meanings:

a) On one hand, this term denotes the decision criteria set out by the highest courts in the Mexican Legal System.

b) On the other, the term is a synonym of "legal science", or "legal doctrine" (or "ciencia del derecho", "doctrina juridica", or "dogmática juridica"). Criminal law theories, the general theory of contracts, the general theory of administrative acts, and so on are typical examples of the kinds of work that go under this heading.

While 'jurisprudence 1' denotes general and abstract explanations of law, 'jurisprudence 2' denotes more specific theories about special areas of the law.

Keeping the subtleties of semantic analysis aside, 'jurisprudence 1' and 'jurisprudence 2' are seen - both by students and legal professionals - as objects of despise.

It is common to hear students and professionals complain about the waste of time that undertaking the study of these subjects ('jurisprudence 1' and 'jurisprudence 2') means because, so they say, these subjects are totally disconnected from real problems and practice.

In the case of 'jurisprudence 1' (or legal philosophy), even Law School deans, faculty, and staff take it as an unimportant, and superfluous subject, due to the fact that they assign the teaching of the subject to people with no experience or teachers of other disciplines. Recently, legal philosophy is starting to simply disappear from the acade- mic programs.

It strikes me as a surprise that this state of affairs obtains in the Anglo-Saxon world as well, despite the fact that the books and papers on the subject are written by full-time professors. 
This aversive attitude towards legal philosophy and legal theory goes back to the origins of the analytic version of the discipline (Nineteenth Century England, with John Austin).

In his "On the Utility of Studying Jurisprudence", Austin states that:

"It is commonly held that the study of the kind of science the utility of which I am arguing may disqualify the student for the practice of the law or may give rise to an aversion towards it. It is probably a fact that some of those who have studied this discipline have revealed themselves as incapable to practice the law or have developed an aversion to it. But despite the appearances in support of this position, I deny that study by itself has the influence attributed by this opinion". ${ }^{6}$

Professor Bix deals with this issue when he says that:

"Why study jurisprudence? For most students, this question has a simple answer: It is a course that they must pass to get a degree. They look at jurisprudence texts as adequate or inadequate means to get what they need: To pass the final examination."7

So, if at some point the aversive attitude towards jurisprudence (legal philosophy) in Mexico seemed to be explained by the set of vices when teaching the subject and by dubious legal theories, the explanation fails if we take into account the analogous situation occurring in countries with much more tradition in the subject.

The common ground of this attitude seems to be an inadequate perception about the benefits of studying philosophy of law, to which I will refer now:

As two sides of the same coin, historically whenever there is an aversive attitude towards legal philosophy, there are also arguments that attempt to justify the benefits of studying it.

6 Austin, John, Sobre la utilidad del estudio de la jurisprudencia, trad. de Felipe González Vicen, México, Editorial Nacional, 1794, p. xii.

7 Bix, Brian, Filosofía del derecho: ubicación de los problemas en su contexto, trad. de Imer B. Flores, Rodrigo Ortiz y Juan Vega, México, UNAM, Instituto de Investigaciones Jurídicas, 2010, p. XVIII. 
For example, Austin thought of jurisprudence as “... the science that reveals the principles, notions and common features that are characteristic of legal systems". 8

From this understanding of jurisprudence we can better comprehend the arguments in favor of its study that Austin advanced:

"It is evident that a man that is familiar with such principles that are independent of any particular legal system will find himself less confused when dealing with Hindu legal institutions than if he only knows them in concrete. He will also feel less inclined to force those institutions into the mold of his country". ${ }^{9}$

Austin's arguments are still valid and today they are complemented by those offered by Professor Bix.

These arguments have to do with the practical benefit of enhancing thought skills, with the intellectual activity of the legal community as a whole, and with the benefits of studying jurisprudence by its own right independently of any additional benefits or advantages one might claim.

Regarding the first argument Bix says: "In a practical level, reading and taking part of jurisprudential discussions tends to develop the skill to think critically and creatively about the law. These skills are essential to legal practice, particularly when facing novel problems or when one tries to formulate new approaches to legal problems". ${ }^{10}$

Regarding the second argument Bix says: "In a professional level, jurisprudence reflects the way in which judges and lawyers think about what they do and about their role in society". ${ }^{11}$

Regarding the third argument, Bix states that: “... finally... jurisprudence is a valuable intellectual endeavor in

8 Ibidem, p. 31.

9 Ibidem, p. 63.

10 Bix, B., op. cit., p. XVIII.

11 Ibidem, p. XIX. 
its own right independently of its other uses and benefits". 12

\section{B) How to Study Jurisprudence (or Philosophy of Law)?}

Despite the aversive attitude towards jurisprudence (or towards what students take jurisprudence to be), it is often the case that one finds students genuinely interested in the subject with a good record of background readings, but unfortunately, with a great confusion surrounding those readings. They have been the victims of "self-learning". This happens because no book in our legal culture includes a section that reviews contemporary methodological issues.

So, Professor Bix's book offers an excellent panoramic vision of the subject in our mexican context where philosophical legal problems are unfortunately presented as metaphysical inquiries of a Platonic stripe.

To begin, Bix's book contends that different legal theories are but different attempts to solve the same problems. He clearly states that different legal theories, contrary to the ordinary perception, try to solve different problems, and that it is necessary to contextualize their conceptual machinery and their set of thesis in order to avoid distortion. He also suggests, quite adequately, that we must focus on the particular questions that the theorist aimed to answer in order to fully understand (and evaluate) his proposals.

Interestingly, Bix uses some basic concepts from the philosophy of science in order to distinguish between conceptual theories and non-conceptual theories. The latter are, as Popper claimed, falsifiable.

After discarding essentialist tendencies (so common in our context) Bix offers a very interesting introduction to conceptual analysis. According to Bix, there are at least four alternatives or modalities of conceptual analysis: 1) Making linguistic stipulations; 2) ordinary usages-based conceptual

12 Idem. 
analysis; 3) conceptual analysis aimed at elucidating what is important regarding the problem under consideration (which is normally hidden under language); 4) determining standards for the use of concepts. He classifies legal conceptual analysis under 3 and 4.

He goes on to describe different proposals for naturalizing jurisprudence, which are but manifestations of the general tendency to naturalize philosophical theories. In this regard he discusses Leiter's project and he critically assess it.

To sum up, Professor Bix's book fills a huge methodological gap in our legal philosophy literature.

\section{C) How to Teach Jurisprudence in Today's Context and How to Become a Legal Philosopher?}

The previous questions may be seen as addressing the students, but these last two questions may be of great importance to those teaching philosophy of law and to those doing research on the subject.

I will analyze them jointly and I will depart from a particular conception of the philosophy of law as a social practice:

The stereotype of the philosopher as a lonely thinker -whose thoughts illuminate our understanding of the world - is deeply rooted in the social representations of the ordinary man, and of many intellectuals as well. A clear example of this stereotype is found in the second section of "The Method" by Descartes.

This image is also present in our context, but despite its initial appeal, it is inadequate if we see it from the perspective of social epistemology. Social epistemology contends the thesis of the exclusive individual knowledge.

Sergio Martinez in this respect claims:

"It is true that epistemology, since Descartes, has been dominated by problems referred to an isolated individual. None- 
theless, no epistemologist has overlooked the obvious fact that our knowledge is mediated by our fellow-humans". ${ }^{13}$

An economic characterization of social epistemology may be found in Kitchner, who says:

"A minimal social epistemology satisfies the following conditions:

1) Primary knowledge agents are individuals... So, attributing knowledge to a community is to make an epistemic assertion about the mental states of its members.

2) "X knows that 'p' if and only if: a) "X believes that 'p", b) ' $\mathrm{p}$ '), and c) ' $\mathrm{X}$ believes that his belief in ' $\mathrm{p}$ ' were formed by a reliable procedure".

3) The reliability of the procedure that produces the shared beliefs that it is the case that ' $p$ ' depends on the properties and actions of agents different from X."14

In the same spirit, Brandom states that:

"... The relationship between the knowledge that is implicit in the practices, and the explicit knowledge expressed in the theories is always mediated by a normative social structure that we must take as the point of departure for an analysis of the cognitive mechanisms. This normative structures is the "space of reasons", a space that is historically construed within which reason-petitions and reason-offerings get articulated as the framework of our knowledge attributions". ${ }^{15}$

As pointed out by Sergio Martinez, scientific traditions are the result of the articulation of scientific practices which on their turn are based on heuristic ${ }^{16}$ structures. These traditions determine the way certain type of knowledge is produced:

13 Martinez, Sergio, Geografía de las prácticas científicas, México, UNAM, Instituto de Investigaciones Filosóficas, colección Filosofia de la Ciencia, 2003, pp. 38 y 39.

14 Ibidem, p. 11.

15 Ibidem, p. 39.

16 Ibidem, p. 118. 
"A scientific tradition is a way of posing problems, of generating explanations, and in general, of producing knowledge based on certain specific practices that characterize the tradition in question. ${ }^{17}$ This does not mean that only one tradition may be attached to a particular field of knowledge. A field of knowledge may admit more than one tradition". ${ }^{18}$

I assume that the previous general characterizations of social epistemology and of the philosophy of science are compatible with a particular conception of the philosophy of law as a social practice and that the development of different legal theories is always the product of a situated cognition.

Despite the fact that Professor Bix does not explicitly refer to legal theories as the product of historically determined social practices, his ideas seem to be compatible with such a conception. So seems to be the case with the proliferation of different legal philosophical traditions.

At this moment it is interesting to point to Julie Dickson's notion of Indirect Evaluative Propositions, which allow us to characterize the methodological and epistemological decisions that the theorist make before engaging in his particular way of theorizing about the law:

"Indirect evaluative propositions such as " $\mathrm{X}$ is important" point to the fact that some $\mathrm{X}$ has evaluative properties, nonetheless such properties are not necessarily moral properties... when someone asserts that $\mathrm{X}$ is an important characteristic he is stating that $\mathrm{X}$ is meaningful and important, and so, worthy of an explanation". 19

Despite the fact that Dickson talks about indirect evaluative propositions of law linking them to analytical theories of law, we consider that the explanatory properties of such a model is powerful enough to cover the existence

17 Ibidem, p. 97.

18 Ibidem, p. 122.

19 Dickson, Julie, Evaluación de la teoría del derecho, trad. de Juan Vega Gómez, México, UNAM, Instituto de Investigaciones Jurídicas, 2006, p. 68. 
of different theories about the law that are widely accepted as valid legal theories, that nonetheless, wouldn't admit to be classified under the heading of "analytical theories".

Following this line of thought, methodological pluralism in legal theory could be explained as different instances of the $\mathrm{X}$ in Dickson's formula. Each instantiation would consider a different property of the law as a relevant one to be explained and as the point of departure of the theoretical endeavor.

This characterization of pluralism in legal theory is consistent with Professor Bix's thought when he says that:

"Legal systems are extremely complex. Inevitably, a theory about law can capture only a portion of the relevant facts... Once one accepts the importance of selection in constructing social theories, the focus then turns to the basis on which selection occurs. "20

As stated before, we must keep in mind, that contrary to ordinary perception, different theories of law aim to answer different questions and different problems:

"It is not surprising that theorists might have had varying criteria for selection, which correspond to different issues which were troubling them or to differing topics that were of their particular interests." 21

Bix highlights the importance of identifying the particular problem in order to understand and evaluate a particular theory in the following way:

"The merits of a conceptual theory may only be assessed once its purpose is clear to us... so the claim I am defending is that the assertions of different conceptual theories have different purposes". ${ }^{22}$

"... Once that we identify that different theorists are addressing different problems and trying to answer different questions it becomes clear how different theorists are describ-

20 Bix, B., op. cit., p. 4.

21 Idem.

22 Ibidem, p. 19. 
ing different aspects of the same phenomenon more than having a disagreement over a simple thesis about the law". ${ }^{23}$

In addition to the diversity of relevant properties as a function of different classes of problems, the construction of different types of legal theories is guided by the methods to make reliable inferences and to offer explanations that will eventually make them able to satisfy certain success standards (coherence, stability, high degree of resistance to counter-arguments), and to provide and answer the problems as they were originally stated.

The relationship between the selection of particular relevant properties, problems, and methodologies gives rise to different types of legal theories. In this regard Bix claims:

"In much of the jurisprudential discussions, what is being considered is not something else than the application to the law of a more general theory in some other area". ${ }^{24}$

So, according to Bix, the characteristic feature of natural law theory is that it is generated considering ethical theory as the point of departure; the characteristic feature of legal positivism is that it is generated taking certain general principles of social theory as the point of departure; critical legal studies take some principles of critical theory as influential; economic analysis of law draws from micro economy; law and literature draws on literary theory; the theories of justice, the moral obligation to obey the law, and the justification of legal punishment draw from moral theories or philosophies; and postmodernist legal theories draw from postmodernism.

In "Jurisprudence, Theory and Context" Professor Bix offers a clear and succinct characterization of these traditions that complements his excellent survey of individual legal theories about the nature of law.

23 Ibidem, p. 3.

24 Ibidem, p. 9. 
Going back to the question on how to teach? Professor Bix's work offers Spanish-speaking teachers the necessary framework to teach their students a panoramic and complete vision of the distinct traditions that are currently at the center of jurisprudential debates.

Our last question, how to become a legal philosopher? Is usually made by those who go beyond teaching and who are interested in research; by those young men who dream that they are participating in the common enterprise of knowledge generation in jurisprudence; who wish to present papers, to attend congresses, and to publish in international peered journals; by those who still belief in the stereotype of the lonely philosopher because they have never been told that legal philosophy, just as any other discipline, is a common endeavor, a social practice with a unifying objective and not an argumentation tournament with winners and losers; a discipline that offers many roads to be traveled by, a host of different problems, and methodologies. All of which is amply and clearly treated in Professor Bix's work.

Because of these reasons I am convinced of the potential that Bix's work has in our context, to give rise to a "beforeand-after scenario" in legal philosophy, at least in this country.

An excellent translation to Spanish of Professor Bix's book is now available. Producing concrete changes is a challenge left to us the readers; a challenge for us teachers, students, and researchers, united by the same passion, by that intangible but fundamental part of our culture which is the Philosophy of Law. 